\title{
THE BASE-RING WARES FROM THE PALACE COMPLEX AT TELL EL-DAB'A ('EZBET HELMI, AREAS H/III AND H/VI)
}

\author{
By Perla Fuscaldo*
}

The Cypriote Base-Ring sherds found in different loci of the palace complex of Tell el-Dabca/Avaris at ${ }^{\mathrm{C}} \mathrm{Ez}-$ bet Helmi (areas H/III and H/VI) ${ }^{1}$ belong to the Base-Ring I ware (twenty-three sherds) - except the handle of a jug (No. 24) that is a Base-Ring II. This pottery is fully described below, in The Catalogue.

The Base-Ring I ware mainly includes sherds from closed shapes. Juglets (Nos. 1-3, 5-7, 12, 15, 18, 21 and 23) and jugs (Nos. 8-11, 20 and 23) are the representative shapes. Open shapes are attested by fragments of five bowls (Nos. 4, 13-14, 17 and 19), two of them rim sherds of carinated bowls (Nos. 17 and 4), and a krater (No. 16). None of the fragments has preserved the wish-bone handle which is a typological characteristic of the bowls.

The Base-Ring ware is hand-made. The fabric is sandy, with a fine or fine to medium groundmass, mainly with few to abundant amounts of quartz particles (between 0.25 and $0.50 \mathrm{~mm}$ ), and with few (sometimes medium) small crushed limestone particles. The walls are very thin and the surface very fine. The wall thickness of juglets, jugs and bowls is between 0.25 and $0.35 \mathrm{~cm}, 0.4 \mathrm{~cm}$ in the krater. The surface is burnished with matte, low, medium or high lustre.

According to the classification made by Sarah Vaughan, ${ }^{2}$ the Base-Ring I sherds from Tell el-Dabca belong to four wares: 1) Base-Ring Slipped - in the variations of Black Matte, Burnished and Metallic, and Brown Burnished; 2) Red Burnished Slipped; 3) Brushed

\footnotetext{
* National Scientific Council (Department of Egyptology, DEGIP-IMHICIHU-CONICET), Buenos Aires, 2002.

1 There are in $\mathrm{H} / \mathrm{VI}$ the palace $\mathrm{G}$, the main palace of the complex, and the palace $\mathrm{J}$, one of the minors, and in $\mathrm{H} / \mathrm{III}$ the offices. See: Ausgrabungen in dem Palastbezirk von Avaris. Vorbericht Tell el-Dabca/cEzbet Helmi 1993-2000, von M. Bietak, J. Dorner und P. JáNOSI, mit einem Beitrag von A. VON DEN DRIESCH. ÄELL 11 (2001) 27-119, specially 48-104, and M. BIETAK, Introduction and Stratigraphic Position of the Deposits, in: P. Fuscaldo, Tell el-Dabca X. The Palace District of Avaris. The Pottery of the Hyksos Period and the New Kingdom (Areas H/III and H/VI). Part II: Two Execration Pits and a Foundation Deposit, 2000. Wien, UZK XVI/2 (in print).
}

Coated - as Black Matte, Brown Matte and Burnished, and Red Burnished -, and 4) Uncoated. It is a classification more related to the surface treatment than to the fabric itself.

Due to the fragmentary condition of the BaseRing wares from CEzbet Helmi, few conclusion can be made from a typological point of view. The carinated bowl No. $17\left(8956 \mathrm{~S}_{1-5}\right.$, Fig. 3a:1, Plate 2:4), ${ }^{3}$ of $16 \mathrm{~cm}$ rim diameter and 0.25 to $0.3 \mathrm{~cm}$ wall thickness, preserves the section quite complete, but the base is missing. This bowl belongs to the Brushed Coated Brown Matte Slipped ware, decorated on both surfaces with a burnished matte mottled slip from reddish brown to weak red and red. It is the most complete shape of all the BR I from these two areas of cEzbet Helmi.

Other shapes are:

1) the rim of a bowl (No. 4, 8953U, Fig. 1: 4, Plate $1: 3), 14 \mathrm{~cm}$ in diameter, which preserves the beginning of the carinated wall. It belongs to the BaseRing Slipped ware, with a medium lustre Black Burnished Slip (dark grey) outside and inside;

2) the body sherd of a bowl (No. 13, 8902J, Fig. 2: $5), 0.25 \mathrm{~cm}$ thick and nearly $14.5 \mathrm{~cm}$ of maximum diameter, with a horizontal straight ridge that usually decorates, below a wave ridge, the hemispherical bowls. ${ }^{4}$ It belongs to the Base-Ring Red Burnished ware with high lustre red slip;

3) the fragments of two pinched ring-based jugs of the Black Burnished Slipped ware. The first one, No.

\footnotetext{
2 Colour Photographs of Base-ring Ware Fabrics, in: P. Åström (ed.), The Chronology of Base-Ring Ware and Bichrome Wheel-Made Ware. Stockholm 2001, 123 and figs. 1-4 (Konferenser 54, KVHAA).

${ }^{3}$ Shape similar to Inv. No. 7946E ('Ezbet Helmi, area $\mathrm{H} / \mathrm{I}$ ), published by I. HeIN, On Bichrome and Base Ring Ware from Several Excavation Areas at cEzbet Helmi, in: P. Åström (ed.), op. cit. (Konferenser 54), 243 and fig. $7,1$.

${ }^{4}$ See Inv. No. 8612O. Bowl type Ia (P. Åström, The Late Cypriote Bronze Age Architecture and Pottery, in: E. GJERSTAD, The Swedish Cyprus Expedition IV,1C, Lund 1972, 138, fig. XLVII, 4). This sherd was classified by Eliezer D. Oren.
} 
8 (8943D, Fig. 1: 8), ${ }^{5}$ of $7 \mathrm{~cm}$ of base diameter, is covered with a medium lustre grey to light brownish grey slip; the second one, No. $9\left(8956 \mathrm{R}_{1-2}\right.$, Fig. 2: 1, Plate $2: 1),{ }^{6}$ a little bigger, has a very dark grey slip;

4) the shoulder of a globular jug, No. $22(8957 \mathrm{H}$, Fig. 3b: 1, Plate 3:4), of ca. $12 \mathrm{~cm}$ of maximum diameter, which preserves two vertical scraping marks inside made to open the neck of the vessel. It is coated with a Brushed Red Burnished slip that mottled the surface in a colour from red to dark reddish grey, with medium lustre;

5) the neck of a juglet, No. 1 (8956Q, Fig. 1: 1, Plate 1:1), an example of a Black Matte Slipped ware, decorated with a horizontal relief of two parallel ridges on the middle of the neck, on a grey to dark grey surface;

6) fragments of a juglet, No. $23\left(8956 \mathrm{~V}_{1-2}\right.$, Fig. 3b: 2, Plate $3: 5),{ }^{7}$ the only example of the Uncoated ware, with a horizontal incised line on the neck-base and an incised line on the shoulder, probably a spiral, made on a pinkish grey burnished surface of matte lustre.

Celia Bergoffen, who has studied the overland trade in northern Sinai during the Late Bronze Age based on the evidence of the Late Cypriote pottery, considers that in Egypt Late Cypriote pottery - in this case the Base-Ring ware - was not a prestige item, because open shapes were hardly attested and the contents of the vessels such as as opium and special oil ${ }^{8}$ were probably of greater interest than the pottery itself.

${ }^{5}$ It was published in: P. Fuscaldo, Preliminary Report of

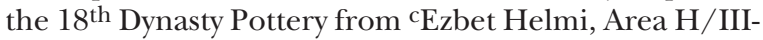
t-u/17 (The Bathroom), ÄELL 11 (2001) 149-166.

${ }^{6}$ See Inv. No. 8477A from Tell el-Dabca ('Ezbet Helmi, area $\mathrm{H} / \mathrm{V}$ ) in I. HeIn, op.cit., in: P. Åström (ed.), op. cit. (Konferenser 54), 242-243 and fig. 7, 3.

7 It is probably similar to the juglet published by $\mathrm{P}$. ÅströM, op. cit., in: E. GJERSTAD, SCE IV,1C, fig. XLIV, 4.

8 Overland Trade in Northern Sinai: The Evidence of the Late Cypriot Pottery, BASOR 294 (1991), 59-90, especially 72-73.

9 Some remarks on the stratigraphy of cEzbet Helmi: the relative stratum e/ 2 corresponds to the Phase $D / 2$, the last Hyksos period, and $e / 1$ to Phase $D / 1$, from the beginning of the Ahmosis occupation of Avaris. The relative stratum $d$ is the Phase $C / 3$ and $c$ the Phase C/2, both phases of the Thutmosid palace-complex at ${ }^{\mathrm{C}}$ Ezbet Helmi; the relative strat $a$ and $a$ were renamed $b / 3$ (Amarna peri$o d$ ) and $b / 2$ (Tutankhamun and Horemheb time) respectively, corresponding both to the Phase $C / 1$. All these strata $(d, c$, and $b)$ were called before absolute Stratum $C$. The Ramesside stratum was renamed Phase b/1 (absolute B), and the Late Period is absolute Phase A. On the stratigraphy
No much information about the first appearance in stratigraphic contexts could be taken from these Base-Ring I wares, except for three sherds from close contexts: the sherd of a juglet, No. 3 (8963L) from the offering pit L4932 (stratum $d=$ Phase C/3), the fragmentary jug No. 8 (8943D) from a floor, L1008, of "the bathroom" (stratum c-d = Phase C/2-C/3), and the carinated bowl No. 4 (8953U), from a room, L4553A, of the workshop (stratum $\mathrm{c}=$ Phase $\mathrm{C} / 2$ ). The others were found in debris, pits or dumps, in stratum $d(=$ Phase $\mathrm{C} / 3)$ and $\mathrm{c}$ from the Tuthmosid period, and in stratum b/3 (= Phase C/1) from the Amarna time and one in stratum b/1 (= absolute stratum B) ${ }^{9}$ a large dump from the Ramesside period (L4791).

The black matte slipped body sherd of a juglet, No. 3 (8963L), appeared in a large collection of more than one hundred vessels in an offering pit from stratum d, L4932, below the dais in the south part of $\mathrm{H} / \mathrm{VI}, \mathrm{x} / 19$, with two Cypriote wheel-made Bichrome sherds and a wheel-made White Painted sherd. ${ }^{10}$

The pinched ring-based black burnished slipped jug No. 8 comes from L1008, a floor of "the bathroom" from the main palace $(\mathrm{G})$, a mud-brick building in the north-east part of the palace complex ${ }^{11}$ (area $\mathrm{H} / \mathrm{III}),{ }^{12}$ located inside the surrounding wall of this palace at the foot of the ramp leading to it. ${ }^{13}$ A large pottery assemblage ${ }^{14}$ was recovered from this bathroom. The ceramics - domestic and votive wares-

of cEzbet Helmi, see M. Bietak, J. Dorner und P. JÁNosi, op. cit., ÄEL 11, 30-47, and M. BIETAK, Introduction..., in: P. Fuscaldo, Tell el-Dabc $a$ X, Part II (in print).

${ }^{10}$ On the stratum d pottery from H/VI, see P. Fuscaldo, Tell el-Dabca X, The Palace District of Avaris. The Pottery from the Hyksos Period and the New Kingdom (Areas H/III and H/VI). Part III: The Pottery from the early mid $18^{\text {th }}$, Dynasty, together with C. KoHEN, S. Vigliani, L. MaRTINEZ and K. PARRI (forthcoming).

11 See: Ausgrabungen in dem Palastbezirk von Avaris. Vorbericht Tell el-Dabca/cEzbet Helmi 1993-2000, von M. Bietak, J. Dorner und P. JÁnosi. ÄẼL 11 (2001), 2.Die Stratigraphie des Palastareals, von M. BIETAK, J. Dorner und P. JÁnOsI, Die Palastanlage der frühen 18. Dynastie Str. $d-c$ (Ph. C/3-2), and fig. 27.

$12 \mathrm{H} / \mathrm{III}-\mathrm{s} / 17, \mathrm{t} / 18-16, \mathrm{u} / 18-15$ and v/17-16.

13 See in the article mentioned in note 1: 3.- Ausgrabungen in den Arealen $H / I I-I I I$ und $H / V I$, von M. BIETAK, J. Dorner und P. JÁnosi, 5.- Der Hauptpalast $(G)$ der 18. Dynastie (Areale H/II-III, H/VI) (Str. $d-c$ ), 74-101, especially 79 and figs. 33-39.

14 See P. Fuscaldo, op. cit. ÄE 211 (2001) 149-164. 
typologically belong to the early mid $18^{\text {th }}$ Dynasty, stratum $\mathrm{c}-\mathrm{d}$ (= Phase $\mathrm{C} / 2-\mathrm{C} / 3)$.

The rim sherd of the carinated bowl No. 4 is a black burnished ware, with a rim of $14 \mathrm{~cm}$, a wall thickness of $0.3 \mathrm{~cm}$ and a high preserved of $2.8 \mathrm{~cm}$. This kind of bowl has a wish-bone handle, not preserved in this example. L4553A, where this bowl comes from, is a room from the workshop area filled with pottery, mud seal-impressions and fragments of mud seal-impressions with royal names of the $15^{\text {th }}$ and $18^{\text {th }}$ Dynasties, from stratum c (= Phase C/2).

The ceramic context from the offering pit L4932 where the Base-Ring I ware juglet sherd No. 3 came from, comprises typical stratum d shapes and wares as: flat-bottomed cups with red-slipped rim band, ring-based bowls with black rim (black rim ware), flat-bottomed small jars with direct everted rim, carinated jars from Middle Bronze Age II B-C origin, ${ }^{15}$ red-slipped burnished dipper juglets of slender type, and local imitations of Middle Bronze Age II B-C ring-based burnished jugs, with angular shoulder, compound rim, double strap handle applied from the neck to the shoulder, ${ }^{16}$ with or without painted decoration, in a fabric made of the Delta or Nile Valley silt clay without organic inclusions or

15 This shape appears in stratum $d$ in two versions, a small jar and a storage jar, and in a finer version with redslipped burnished surface in stratum c, all of them in Nile silt clay.

16 R. Amiran, Ancient Pottery of the Holy Land. Jerusalem 1969, plate 34:12, from Megiddo.

17 No Black Rim ware is found before stratum d, i.e. in the earliest stratum of the $18^{\text {th }}$ Dynasty, e/1.

18 White Painted $V$ is a Middle Bronze ware that appears in Tell el-Dabca in stratum d/2 (= Phase D/2).

19 V. Karageorghis (ed.), The White Slip Ware of Late Bronze Age Cyprus. Proceedings of an International Conference organized by the Anastasios G. Leventis Foundation, Nicosia, in honour of M. Wiener, Nicosia, 29th-30th October 1998. Wien 2002 (ÖAW XX; Contributions to the Chronology of the Eastern Mediterranean, ed. by M. BIETAK and H. Hunger, II). On the published material from Tell el-Dabca see 171-194, The Context of White Slip wares in the Stratigraphy of Tell el-Dabca and some Conclusions on Aegean Chronology, by M. BIETAK and I. HeIN. On the White Slip ware from Tell el-Dabca at 'Ezbet Helmi, Area H/VI: P. Fuscaldo, The White Slip Ware from the Palace Complex at Tell el-Dabca ( ${ }^{\mathrm{c} E z}$ bet Helmi, Areas H/VI and H/III) (forthcoming).

${ }^{20}$ In I. HeIn, op. cit., in: P. Åström (ed.), op. cit. (Konferenser 54), mentioned in note 2 , there is no reference to the strata where the Base-Ring ware from areas $\mathrm{H} / \mathrm{I}$, IV and V appeared.

${ }^{21}$ A preliminary characterisation of the stratum-d shapes with crushed limestone particles.

The Base-Ring I ware jug No. 8, from L1008, is associated with the Egyptian Black Rim ware $^{17}$ (bowls and jars), red-slipped polished cups with incurved rim and pointed base finished on the wheel, fine footed bowls and concave bowls, small burnished bowls, a burnished globular jug made of the Delta silt clay tempered with fine grained quartz, and fine imports from Cyprus (White Painted $V^{18}$ Bichrome wheel-made and Red Lustrous wheel-made ware). No White Slip ware was found in this locus. ${ }^{19}$

Base-Ring I ware is found in Tell el-Dabca, areas $\mathrm{H} / \mathrm{III}$ and VI, from stratum d onwards, ${ }^{20}$ but only three sherds in closed contexts: an offering pit (L4932) from stratum d, a floor (L1008) from "the bathroom", stratum d-c, and a floor (L4553A) from the workshop, stratum c. There is no great difference from a typological point of view between the pottery from stratum $\mathrm{d}$ and $\mathrm{c}^{21}$ In the stratum $\mathrm{d}$ there are nearly the same Egyptian and imported pottery shapes and wares mentioned above, in L4932, and L1008 and other loci of "the bathroom" - except Red Lustrous wheel-made ware. Egyptian Bichrome ware is found beside Cypriote wheel-made Bichrome in stratum d contexts, but both are more

and wares reveals: 1) few small bowls with burnished interior surface; white-washed jars (WF-Vase) in two versions, white-washed and white-slipped, with trimmed or rounded rim; fine footed bowls, with a red-slipped and red-slipped polished surface, straight sided or with incurved rim; black-rim ware (ring-based bowls, straight sided and with interior lip, and small flat-based jars with direct everted rim are the representative shapes); 2) local imitations of MB Age II B-C ring-based burnished jars, with angular shoulder, compound rim, double strap handle applied from the neck to the shoulder, with or without painted decoration, in a fabric made of the Delta or Nile Valley silt clay without organic inclusions or crushed limestone particles, which is not included in the "Vienna System" - this ware is not found anymore in stratum c; 3) the weak red or red-slipped burnished dipper juglets from Middle Bronze Age II B-C origin, which in stratum c are still used beside a more finer juglet with a light redslipped polished surface; 4) occasionally Egyptian painted wares; 5) Cypriote Bichrome wheel-made ware, but in less amount that in stratum c; 6) no Cypriote Red Lustrous ware; 7) occasionally White Slip I ware. The most common fabric is Nile $\mathrm{B}_{2}$ sandy $\left(=\right.$ Nile $\left.\mathrm{E}_{4}\right)$. On the stratum e/ 1 and d shapes: P. FusCALDO, A Preliminary Report on the Pottery from the Strata e/1 (=Phase $\mathrm{D} / 1)$ and $\mathrm{d}(=$ Phase $\mathrm{C} / 3)$ at ${ }^{\mathrm{C}}$ Ezbet Helmi, H/VI (forthcoming). The stratum c pottery from $\mathrm{H} / \mathrm{VI}$ is being studied by David Aston. 
abundant in stratum c. A Black Lustrous ware appeared in L3005, ${ }^{22}$ a closed context ${ }^{23}$ inside the terrace between the exterior wall of the palace $\mathrm{G}$ and the enclosure wall of the same building, which belongs to the first phase of construction of this palace (stratum $\mathrm{d}=$ Phase $\mathrm{C} / 3$ ).

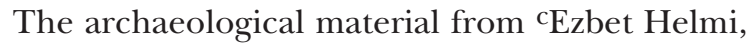
$\mathrm{H} / \mathrm{VI}$ South, recovered during the excavations made in 2001 and 2002, has given new elements for dating the New Kingdom palace complex. Bietak ${ }^{24}$ proposes now a date into the Thutmosid period, with two phases of construction, the first one at the beginning of the reign of Thutmosis III and the second one, with especial modifications in the palace $G$ and southwards, ${ }^{25}$ from the time of this king to the reign of Amenophis II.

Base-Ring II ware is rarely represented. The only example (No. 24) comes from the area $\mathrm{H} / \mathrm{III}$ and was found in the accumulation of earth produce by the excavations of a modern canal.

According to Eliezer Oren, Base-Ring I ware does not appear in quantity before the time of Thutmosis III. ${ }^{26}$ Kathryn Eriksson ${ }^{27}$ claims that Base-Ring I and Red Lustrous wheel-made wares can be dated closely to the reign of Thutmosis III in Canaan, and that the bulk of these imports can be from the reign of this pharaoh, the period when most of these wares appeared in Egypt.

\section{The Catalogue}

\section{BASE-RING I}

\section{Base-Ring Slipped Ware}

\subsection{Black Matte Slip}

No. 1: Juglet, Inv. No. 8956Q \{2002/110\} (Fig. 1: 1, Pl. 1:1) Field reference: $H / V I-w / 18, P l .4, L 4813$, stratum c-d (= Phase C/2-C/3), a large pottery collection, probably a dump. Find No. 1.

\begin{tabular}{|l|l|l|l|l|l|l|} 
SP & VI & fine & $\mathrm{Ha}_{1}$ & - & re & 3 \\
\hline
\end{tabular}

Neck fragment, $1 / 2$ preserved. $\mathrm{Nd}: 1.6 \mathrm{~cm}$; Wd: $0.3 \mathrm{~cm} ; \mathrm{H}_{3}$ : $5.0+\mathrm{x} \mathrm{cm}$.

Surface colour: 7.5YR 6/2 pinkish grey interior; slip: 7.5YR 5/1 grey- 4/1 dark grey. Break: 7.5YR 5/1 grey.

Inclusions: quartz ( $>0.25 \mathrm{~mm}$ : medium; $<2 \mathrm{~mm}$ : very few),

22 The pottery assemblage from L3005 and from other stratum d loci of the same area, will be published in P. Fuscaldo, Tell el-Dabc $a$ X, Part III (see above, note 10).

23 The only one in H/VI North, on the north-west part of the palace $\mathrm{G}$.

24 Introduction and Stratigraphic Position of the Deposits, in: Tell el-Dabca X, Part II.

${ }_{25}$ On the workshops and other areas south to the palace G, stratum c, see M. BIETAK (ed.), (forthcoming). crushed limestone particles (>0.25 mm: very few) and dark sand. The fabric is less porous and finer than BR II (8205Q). Technical details: marks of the stick used to open the neck.

Decoration: a horizontal relief of two parallel ridges on the middle of the neck.

Surface treatment: burnished, matte lustre.

No. 2: Juglet, Inv. No. 8956 T-2 $\left.{ }_{1-2} 2002 / 101\right\}$ (Fig. 1: 2, Pl. 1:2) Field reference: $H / V I-x / 19, P l .1-2, L 4840(L)$, stratum $d$ (= Phase C/3), a dump with a large amount of pottery sherds (L4840 and L4840A to H).

\begin{tabular}{|c|c|c|c|c|c|c|}
\hline SP & VI & f.-med. & $\mathrm{Ha}_{1}$ & - & re & 3 \\
\hline
\end{tabular}

Two body sherds. Wd: $0.25 \mathrm{~cm} ; \mathrm{H}_{1}: 3.8+\mathrm{x} \mathrm{cm}$.

Surface colour: 10YR 5/1 grey interior; slip: 10YR 3/1 very dark grey.

Break: 7.5YR 3/1 very dark grey-2.5/1 black.

Inclusions: quartz $(>0.25 \mathrm{~mm},>0.50 \mathrm{~mm}$ : abundant), crushed limestone particles $(>0.25 \mathrm{~mm}$ : few) and dark sand (very fine). The fabric is coarser than BR I 8955R. Burnished, matte lustre.

No. 3: Juglet, Inv. No. 8963L \{2002/192\} (Fig. 1: 3)

Field reference: $H / V I-x / 19, P l .3$, L4932, stratum $d$ (= Phase $C / 3$ ), an offering pit.

\begin{tabular}{|c|c|c|c|c|c|c|}
\hline SP & VI & fine & $\mathrm{Ha}_{1}$ & - & re & 3 \\
\hline
\end{tabular}

Body sherd. Wd: $0.2 \mathrm{~cm} ; \mathrm{H}_{1}: 2.5+\mathrm{x} \mathrm{cm}$.

Surface colour: 5YR $6 / 6$ yellowish red outside; 10YR 6/1 grey inside; 10YR 4/1 dark grey slip.

Break: 10YR 5/1 grey.

Inclusions: quartz $(>0.25 \mathrm{~mm},>0.50 \mathrm{~mm}$ : abundant; $>2$ $\mathrm{mm}$; few), crushed limestone particles $(>0.25 \mathrm{~mm}$ : few $)$.

Finger prints inside, near [the base]; burnished, matte lustre.

\subsection{Black Burnished Slip}

No. 4: Carinated bowl, Inv. No. 8953U $\{2002 / 315\}$

(Fig. 1: 4, Pl. 1:3)

Field reference: $H / V I-v / 17, P l .2, L 4553 A$, stratum c (= Phase $C / 2$ ), a room from the workshop area filled with pottery, mud sealimpressions and fragments of mud seal-impressions with royal names of the $15^{\text {th }}$ and $18^{\text {th }}$ Dynasties; from K-9077.

\begin{tabular}{|c|c|c|c|c|c|c|}
\hline SP & VI & fine & $\mathrm{Ha}_{1}$ & - & re & 3 \\
\hline
\end{tabular}

Rim sherd, 3/64; Rd: 14.0 cm; Wd: 0.3 cm; $\mathrm{H}_{1}: 2.8+\mathrm{x}$ cm. Surface colour: 7.5YR 4/1 dark grey slip outside and inside. Break: 7.5YR 4/1 dark grey.

Inclusions: quartz ( $>0.25 \mathrm{~mm}$ : abundant), crushed limestone particles $(>0.25 \mathrm{~mm}$ : very few).

Bowl with [wish-bone handle]; burnished, medium lustre.

${ }^{26}$ Cypriot Imports in the Palestinian Late Bronze I Context, Op. Ath 9 (1969), 127-150.

27 Cypriot Ceramics in Egypt during the Reign of Thutmosis III: The Evidence of Trade of Synchronizing the Late Cypriot Cultural Sequence with Egypt at the Beginning of the Late Bronze Age, in: P. Åström (ed.), op. cit. (Konferenser 54), 51-68, especially 51-53. 
No. 5: Juglet, Inv. No. 8955Z $1-2\{2002 / 088\}$ (Fig. 1: 5, Pl. 1:4) Field reference: $H / V I-v / 18, P l$. 1, L4792, stratum c (= Phase $C / 2$ ), from the upper part of the reddish fill of a room, south of the palace $G$.

\begin{tabular}{|c|c|c|c|c|c|c|}
\hline SP & VI & f.-med. & $\mathrm{Ha}_{1}$ & - & re & 3 \\
\hline
\end{tabular}

Body sherd. Wd: $0.25 \mathrm{~cm} ; \mathrm{H}_{1}: 3.0+\mathrm{x} \mathrm{cm}$.

Surface colour: 7.5YR 4/1 dark grey interior; slip: 5YR 4/1 dark grey.

Break: 5YR 4/1 dark grey-3/1 very dark grey.

Inclusions: quartz $(>0.25 \mathrm{~mm},>0.50 \mathrm{~mm}$ : abundant), crushed limestone particles $(>0.25 \mathrm{~mm}$ : few) and dark sand (very fine). The fabric is similar to BR I 8956T.

Decoration: a circular ridge partially preserved. Burnished, low lustre.

No. 6: Juglet, Inv. No. 8957A \{2002/109\} (Fig. 1: 6, Pl. 1:5) Field reference: $H / V I-v / 19, P l .2, L 4878$, stratum b/3-c (= Phase C/1-C/2), from the upper fill of a pit, possibly a dump.

\begin{tabular}{|c|c|c|c|c|c|c|}
\hline SP & VI & fine & $\mathrm{Ha}_{1}$ & - & re & 3 \\
\hline
\end{tabular}

Body sherd. Md: ca. $16.0 \mathrm{~cm}$; Wd: $0.25 \mathrm{~cm} ; \mathrm{H}_{1}: 1.1+\mathrm{x} \mathrm{cm}$ Surface colour: 7.5YR 6/1 grey interior; slip: 5YR 4/1 dark grey.

Break: 7.5YR 4/1 dark grey interior (thick zone); 6/3 light brown exterior (thin zone).

Inclusions: quartz ( $>0.25 \mathrm{~mm},>0.50 \mathrm{~mm}$ : abundant), crushed limestone particles $(>0.25 \mathrm{~mm}$ : few) and dark sand (very fine). The fabric is as fine as $8955 \mathrm{R}$.

Burnished, low lustre.

No. 7: Juglet?, Inv. No. 8953B \{2002/315\} (Fig. 1: 7, Pl. 1:6) Field reference: $H / V I-w / 19, P l .1, L 4825$, stratum b/3-c (= Phase C/1-C/2), a dump below L4823.

\begin{tabular}{|c|c|c|c|c|c|c|}
\hline SP & VI & f.-med. & $\mathrm{Ha}_{1}$ & - & re & 3 \\
\hline
\end{tabular}

Body sherd; Wd: $0.3 \mathrm{~cm} ; \mathrm{H}_{1}: 2.5+\mathrm{x} \mathrm{cm}$.

Surface colour: 5YR 6/4 light reddish brown; 3/1 very dark grey slip outside.

Break: 5YR 6/1 grey.

Inclusions: quartz ( $>0.25 \mathrm{~mm},>0.50 \mathrm{~mm}$ : abundant), mica (few), crushed limestone particles (>0.25 mm: very few).

Decoration: a horizontal ridge. Burnished, medium lustre.

No. 8: Jug, Inv. No. 8943D \{2001/114\} (Fig. 1: 8)

Field reference: $H / I I I-t / 17, P l . ~ 1, L 1008$, stratum $c-d$ (= Phase C/2-C/3). the floor of "the bathroom" in the Palace G.

\begin{tabular}{|c|c|c|c|c|c|c|}
\hline SP & VI & f.-med. & $\mathrm{Ha}_{1}$ & Bd. Ha & re & 3 \\
\hline
\end{tabular}

Base fragment; pinched ring base $\left(\mathrm{R}_{1}\right) . \mathrm{Bd}: 7.0 \mathrm{~cm} \mathrm{1/16}$; Wd: $0.25 \mathrm{~cm} ; \mathrm{H}_{1:} 1.3+\mathrm{x} \mathrm{cm}$.

Surface colour: 10YR 6/3 pale brown; slip: 10YR 5/1 grey $-6 / 2$ light brownish grey.

Break: 10YR 5/1 grey.

Inclusions: quartz $(>0.25 \mathrm{~mm}$ : abundant; $<0.50 \mathrm{~mm}$ : medium), crushed limestone particles $(>0.25 \mathrm{~mm}$ : few). Some voids.

Burnished, medium lustre.

No. 9: Jug, Inv. No. $8956 R_{1-2}\{2002 / 110\}$ (Fig. 2: 1, Pl. 2: 1) Field reference: H/VI-v/19, Pl. 1, L4829, stratum b/3-c (= Phase C/1-C/2), found in mud at the border of the pit L4830. $H: 4.85 \mathrm{~m}$.

\begin{tabular}{|c|c|c|c|c|c|c|}
\hline SP & VI & fine & $\mathrm{Ha}_{1}$ & $\mathrm{Bd} . \mathrm{Ha}$ & re & 3 \\
\hline
\end{tabular}

Base, 9/32 preserved, and body fragment; pinched ring base $\left(\mathrm{R}_{1}\right)$. Md: $14.0+\mathrm{x} \mathrm{cm}$; Bd: $8.0 \mathrm{~cm}$; Wd: $0.35 \mathrm{~cm} ; \mathrm{H}_{1}$ : $5.2+\mathrm{x} \mathrm{cm}$.

Surface colour: 7.5YR 4/3 brown interior; slip: 7.5YR 3/1 very dark grey.

Break: 7.5YR 4/1 dark grey interior (thick); 5YR 6/8 reddish yellow exterior (thin).

Inclusions: quartz (>0.25 mm: abundant), crushed limestone particles $(>0.25 \mathrm{~mm}$ : few $)$, red grit? The fabric is less sandy than $8956 \mathrm{Q}$ but with more limestone particles. Burnished, medium lustre

No. 10: Jug, Inv. No. 8945H \{2002/315\} (Fig. 2: 2)

Field reference: $H / V I-v / 16, P l$. 0-1, L4561, stratum b/3 (= Phase C/1), dark mud-brick debris.

\begin{tabular}{|c|c|c|c|c|c|c|}
\hline SP & VI & fine & $\mathrm{Ha}_{1}$ & - & re & 3 \\
\hline
\end{tabular}

Body sherd; Wd: $0.35 \mathrm{~cm}: \mathrm{H}_{1}: 4.5+\mathrm{x} \mathrm{cm}$

Surface colour: 7.5YR 5/3 brown inside; 7.5YR 4/1 dark grey slip outside.

Break: 7.5YR 4/1 dark grey core (thick zone); a very thin exterior zone 5YR 6/4 light reddish brown.

Inclusions: quartz ( $>0.25 \mathrm{~mm}$ : abundant), crushed limestone particles $(>0.25 \mathrm{~mm}$ : few $)$.

Burnished, medium lustre.

\subsection{Black Metallic Slip}

No. 11: Jug, Inv. No. 8955Y $\mathrm{Y}_{1-2}\{2002 / 111\}$ (Fig. 2: 3, Pl. 2: 2) Field reference: $H / V I-u / 18, P l$. O-1, L4707, stratum b/3-c (= Phase C/1-C/2), dark mud-brick debris at the top of stratum c wall.

\begin{tabular}{|c|c|c|c|c|c|c|}
\hline SP & VI & fine & $\mathrm{Ha}_{1}$ & - & ox & 3 \\
\hline
\end{tabular}

Body sherd with part of the base of the handle. Wd: $0.35 \mathrm{~cm}$; $\mathrm{H}_{1}: 2.8+\mathrm{x} \mathrm{cm}$.

Surface colour: 7.5YR 5/2 brown interior; slip: 7.5YR 2.5/1 black.

Break: 7.5YR 4/1 dark grey interior (thick); a very thin oxidation zone (5YR $6 / 6$ reddish yellow) on the exterior. Inclusions: quartz (>0.25 mm, $>0.50 \mathrm{~mm}$ : abundant), crushed limestone particles $(>0.25 \mathrm{~mm}$ : few) and dark sand (very fine). Fabric similar to 8957A.

The body sherd preserves part of the base of the handle [which is pushed through into the wall]; burnished, high lustre.

\subsection{Brown Burnished Slip}

No. 12: Juglet (or Jug?), Inv. No. 8891N \{1999/131\} (Fig. 2: 4)

Field reference: $H / I I I-p / 19, P l .3-4$, Locus -, stratum b/3 (= Phase C/1); from K-6374. ${ }^{28}$ Found by the wall.

\begin{tabular}{|c|c|c|c|c|c|c|}
\hline BP & VI & f.-med. & $\mathrm{Ha}_{1}$ & - & ox & 3 \\
\hline
\end{tabular}

Neck and base-neck; handle from upper neck to [shoulder]. Nd: $1.4-2.1 \mathrm{~cm}$; Wd: $0.25-0.3 \mathrm{~cm} ; \mathrm{H}_{1}: 5.1+\mathrm{x} \mathrm{cm} ; \mathrm{H}_{3}$ : $4.9+$ x cm; Hd: 1.2 x $0.6 \mathrm{~cm}$.

Surface colour: 5YR 6/6 reddish yellow; slip: 7.5YR 5/4 brown.

Break: 5YR 5/1 grey interior (thick zone); a very thin oxi-

\footnotetext{
${ }^{28}$ It was checked in Tell el-Dabca by Celia Bergoffen.
} 
dation zone (6/6 reddish yellow) on the exterior. Inclusions: quartz (>0.25 $\mathrm{mm}, 0.50 \mathrm{~mm}$ : abundant), crushed limestone particles $(>0.25 \mathrm{~mm}$ : few; $>0.50 \mathrm{~mm}$ : occasionally) and black grit. Voids.

Narrow pulled-back cylindrical neck, with handle from neck to shoulder, one strap, rectangular in section; vertical stick marks inside the neck, from a stick used to open it. Decoration: a horizontal ridge all around the neck and on the middle of it at the junction with the handle. Burnished, medium lustre preserved in some parts.

\section{Base-Ring Red Burnished}

No. 13: Bowl, Inv. No. 8902 \{1999/129\} (Fig. 2: 5) Field reference: $H / I I I-p / 19, P l .0-1$, Locus -, stratum a [now renamed stratum $b / 2$ (= Phase $C / 1)$, mud-brick debris at the top of the stratum b/3 (= Phase C/1) wall; $0.6 \mathrm{~cm}$ below the surface. $H$ : 4.45-4.58 m; from $\mathrm{K}-6272$.

\begin{tabular}{|l|c|c|c|c|c|c|} 
RP & VI & fine & $\mathrm{Ha}_{1}$ & - & ox & 3 \\
\hline
\end{tabular}

Body sherd; [wish-bone handle]. Md: ca. $14.5+\mathrm{x} \mathrm{cm}$; $\mathrm{Wd}: 0.25 \mathrm{~cm}$

Surface colour: 2.5YR 5/8 red slip (outside and inside).

Break: 5YR 5/2 reddish grey core; $5 / 6$ yellowish red oxidation zones.

Inclusions: quartz ( $>0.25 \mathrm{~mm}$ : abundant; $>2 \mathrm{~mm}$ : occasionally), crushed limestone particles $(>0.25 \mathrm{~mm},>0.50$ $\mathrm{mm}$ : few to medium) and red grit. Voids.

Hemispherical bowl with [wish-bone handle].

Decoration: a horizontal straight ridge. Burnished inside and outside, high lustre.

No. 14: Bowl, Inv. No. 8612O \{1997/053\} (Fig. 2: 6) Field reference: $H / I I I-q / 16, P l .2-3$, Locus -, stratum d (= Phase C/3), an accumulation of mud at the top of the stratum e wall. H: 4.50-4.70 m; from $\mathrm{K}-6192 .^{29}$

\begin{tabular}{|l|l|l|l|l|l|l|}
\hline RP & VI & fine & $\mathrm{Ha}_{1}$ & - & me & 3 \\
\hline
\end{tabular}

Body sherd. Wd: $0.3 \mathrm{~cm} ; \mathrm{H}_{1}: 2.8+\mathrm{x} \mathrm{cm}$.

Surface colour: 2.5YR 6/8 light red slip (outside and inside).

Break: 2.5YR 6/1 reddish grey-6/2 pale red core; very fine oxidation zones (6/4 light red).

Inclusions: quartz $(>0.25 \mathrm{~mm}$ : abundant; $>2 \mathrm{~mm}$ : occasionally), crushed limestone particles $(>0.25 \mathrm{~mm},>0.50$ mm: medium) and red grit. Voids.

Very fine bowl; burnished inside and outside, high lustre.

No. 15: Juglet, Inv. No. 8903V \{1999/152\} (Fig. 2: 7)

Field reference: $H / I I I-o / 18, P l .0-1, L 25$, stratum $a-b$ (now renamed stratum $b / 2$ and $b / 3$ respectively (= Phase $C / 1)$, the upper part of the sand fill $(15 \mathrm{~cm}$ high) at the border of the trench); from K-6292. ${ }^{30}$

\begin{tabular}{|c|c|c|c|c|c|c|}
\hline RP & VI & fine & $\mathrm{Ha}_{1}$ & - & ox & 3 \\
\hline
\end{tabular}

Body sherd. Wd: $0.35 \mathrm{~cm}$

Surface colour: $2.5 Y R$ 6/2 pale red interior; 6/6 light red exterior (eroded).

Break: 7.5YR 6/4 light brown interior (thick zone); a very thin oxidation zone (2.5YR 6/6 light red) on the exterior. Inclusions: quartz ( $>0.25 \mathrm{~mm}$ : abundant), crushed limestone particles $(>0.25 \mathrm{~mm}$ : medium; $>0.50 \mathrm{~mm}$ : few $)$, red grit. Some voids.

Eroded exterior surface [burnished].

\section{Base-Ring with brushed coating}

\subsection{Brushed Black Matte Slip}

No. 16: Krater, Inv. No. 8956U \{2002/090\} (Fig. 2: 8, Pl. 2: 3) Field reference: $H / V I-x / 19, P l .1-2, L 4840(L)$, stratum $d(=$ Phase C/3), a dump with a large amount of pottery sherds (L4840 and L4840 A to H).

\begin{tabular}{|c|c|c|c|c|c|c|}
\hline SP & VI & fine & $\mathrm{Ha}_{1}$ & - & ox & 3 \\
\hline
\end{tabular}

Body sherd. Wd: $0.4 \mathrm{~cm} ; \mathrm{H}_{1}: 3.1+\mathrm{x} \mathrm{cm}$..

Surface colour: 5YR 7/4 pink interior; slip: 7.5YR 4/1 dark grey.

Break: 5YR 5/8 yellowish red.

Inclusions: quartz $(>0.25 \mathrm{~mm}$ : abundant $)$, crushed limestone particles $(>0.25 \mathrm{~mm}$ : medium; $>0.50 \mathrm{~mm}$ : few $)$, red grit. Voids.

Decoration: a horizontal ridges on the body. Burnished, matte lustre.

\subsection{Brushed Brown Matte Slip Ware}

No. 17: Carinated bowl, Inv. No. $8956 \mathrm{~S}_{1-5}\{2002 / 111\}$

(Fig. 3a: 1, Pl. 2: 4)

Field reference: $H / V I-x / 19, P l .1-2, L 4840(L)$, stratum $d(=$ Phase C/3) ), a dump with a large amount of pottery sherds (L4840 and L4840 A to H).

\begin{tabular}{|c|c|c|c|c|c|c|}
\hline BP & VI & fine & $\mathrm{Ha}_{1}$ & - & ox & 3 \\
\hline
\end{tabular}

Rim, 3/64 preserved, and body sherds. 1) and 2) Rd: $16.0 \mathrm{~cm}$; Wd: $\left.0.3 \mathrm{~cm} ; \mathrm{H}_{1}: 7.0+\mathrm{x} \mathrm{cm} .3\right)$ and 4) Wd: $0.25-$ $0.3 \mathrm{~cm} ; 5) \mathrm{Wd}: 0.25 \mathrm{~cm}$.

Surface colour: 2.5YR 5/4-4/4 reddish brown-4/2 weak red-5/8 red slip.

Break: 5YR 6/4 light reddish brown-6/6 reddish yellow. Inclusions: quartz ( $>0.25 \mathrm{~mm}$ : medium), crushed limestone particles $(>0.25 \mathrm{~mm}$ : medium). The fabric is less sandy and finer than the BR Black Slip ware.

Decoration: mottled slip from reddish brown to weak red and red.

Burnished, matte lustre.

No. 18: Juglet with everted rim, Inv. No. 8958A $\{2002 / 110\}$ (Fig. 3a: 2, Pl. 3: 1)

Field reference: $H / V I-v / 19, P l .2, L 4878$, stratum b/3-c (= Phase C/1-C/2), a pit, probably a dump. Find No. 66, below Find No. 65.

\begin{tabular}{|c|c|c|c|c|c|c|} 
BP & VI & f.-med. & $\mathrm{Ha}_{1}$ & - & re & 3 \\
\hline
\end{tabular}

Rim sherd, 1/8 preserved. Rd: 8.0 cm; Wd: 0.25 cm; $\mathrm{H}_{1}: 2.3$ $+\mathrm{x} \mathrm{cm}$.

Surface colour: 10YR 3/1 very dark grey-4/2 dark greyish brown slip outside; 7.5YR 5/3-4/3 brown slip inside. Break: 7.5YR 5/1 grey.

Inclusions: quartz $(>0.25 \mathrm{~mm},>0.50 \mathrm{~mm}$ : abundant),

${ }^{29}$ See TD Inv. No. 8902J. It was checked by Celia Bergoffen.

30 The sherd was classified by Celia Bergoffen. 
crushed limestone particles (>0.25 mm: few).

Decoration: mottled slip from very dark grey to dark greyish brown and brown.

Burnished; matte outside, medium lustre inside.

\subsection{Brushed Brown Burnished Slip}

No. 19: Bowl, Inv. No. 8953H $\{2002 / 315\}$ (Fig. 3a: 4, Pl. 3:2) Field reference: H/VI-s/11, Pl. 1-2, L4052, stratum b/3-c (= Phase C/1-C/2), mud-brick debris.

\begin{tabular}{|c|c|c|c|c|c|c|}
\hline BP & VI & f.-med. & $\mathrm{Ha}_{1}$ & - & re & 3 \\
\hline
\end{tabular}

Body sherd; Wd: $0.35 \mathrm{~cm} ; \mathrm{H}_{1}: 2.5+\mathrm{x} \mathrm{cm}$.

Surface colour: 7.5YR 5/6 strong brown and 3/1 dark brown slip outside and inside.

Break: 7.5YR 7/1 light grey.

Inclusions: quartz $(>0.25 \mathrm{~mm}$ : abundant; $>0.50 \mathrm{~mm}$, $<2 \mathrm{~mm}$ : few), mica (few), crushed limestone particles $(>0.25 \mathrm{~mm}$ : few); voids.

Bowl with [wish-bone handle].

Decoration: mottled slip from strong brown to dark brown.

Burnished, high lustre.

No. 20: Jug, Inv. No. 8956P \{2002/111\} (Fig. 3a: 3) Field reference: $H / V I-v / 19, P l .1$, L4829, stratum b/3-c (= Phase $C / 1-C / 2)$. Found in mud in the southwest corner of the square, together with a collection of large vessels, south of the wall M1218.

\begin{tabular}{|c|c|c|c|c|c|c|}
\hline BP & VI & fine & $\mathrm{Ha}_{1}$ & - & ox & 3 \\
\hline
\end{tabular}

Body sherd. Nd: $5.0 \mathrm{~cm}$; Wd: $0.35 \mathrm{~cm} ; \mathrm{H}_{1}: 3.5+\mathrm{x} \mathrm{cm}$; $\mathrm{H}_{3}: 2.6+\mathrm{x} \mathrm{cm}$.

Surface colour: 2.5YR 6/6 light red interior; slip: 2.5YR $3 / 3$ dark reddish brown $-4 / 3$ reddish brown.

Break: 2.5YR 4/1 dark grey core; 2.5YR 6/6 light red oxidation zones.

Inclusions: quartz ( $>0.25 \mathrm{~mm}$ : abundant; $>0.50 \mathrm{~mm}$ : medium), crushed limestone particles ( $>0.25 \mathrm{~mm}$ : medium) and red grit. Voids.

Burnished, medium to low lustre.

\subsection{Brushed Red Burnished Slip}

No. 21: Juglet, Inv. No. $8956 \mathrm{~W}_{1-4}\{2002 / 109\}$

(Fig. 3a: 5, Pl. 3:3)

Field reference: $H / V I-v / 19, P l .1, L 4829$, stratum b/3 (= Phase $C / 1)$. Found in mud in the southwest corner of the square, together with a collection of large vessels, south of the wall M1218.

\begin{tabular}{|l|c|c|c|c|c|c|}
\hline $\mathrm{RP} / \mathrm{SP}$ & $\mathrm{VI}$ & fine & $\mathrm{Ha}_{1}$ & - & ox & 3 \\
\hline
\end{tabular}

Body sherds. Wd: 0.28-0.3 cm. 1) $\mathrm{H}_{1}: 5.0+\mathrm{x} \mathrm{cm}$; 2) $\mathrm{H}_{1}: 2.0$ $+\mathrm{x} \mathrm{cm}$.

Surface colour: 2.5YR 6/6 light red interior; slip: 5/6 red and $4 / 1$ dark reddish grey exterior.

Break: 2.5YR 4/1 dark reddish grey core; 6/6 light red oxidation zones.

Inclusions: quartz ( $>0.25 \mathrm{~mm}$ : medium; $<2 \mathrm{~mm}$ : occasionally), crushed limestone particles $(>0.25 \mathrm{~mm}$ : medium; $>0.50 \mathrm{~mm}$ : few). Voids. The fabric is less sandy and finer than BR Black Slip ware.

Decoration: mottled slip from red to dark reddish grey.

Burnished, low to medium lustre.
No. 22: Jug, Inv. No. 8957H \{2002/315\} (Fig. 3b: 1, Pl. 3:4) Field reference: $H / V I-v / 18, P l .1, L 4791$, stratum b/1 (Ramesside, $=B$ ), a large dump.

\begin{tabular}{|l|l|l|l|l|l|l|}
\hline $\mathrm{RP} / \mathrm{SP}$ & $\mathrm{VI}$ & fine & $\mathrm{Ha}_{1}$ & - & ox & 3 \\
\hline
\end{tabular}

Shoulder sherd Md: ca. $12.0 \mathrm{~cm}$; Wd: $0.35 \mathrm{~cm}$; $\mathrm{H}_{1}: 4.8+$ $\mathrm{x} \mathrm{cm}$.

Surface colour: 2.5YR 6/6 light red; 2.5 YR 5/6 red and 4/1 dark reddish grey slip outside.

Break: 2.5YR 4/1 dark reddish grey core; 6/6 light red oxidation zones.

Inclusions: quartz (>0.25 mm, $>0.50 \mathrm{~mm}$ : abundant), crushed limestone particles $(>0.25 \mathrm{~mm},>0.50 \mathrm{~mm}$ : few). Scraping marks inside made to open the neck.

Decoration: mottled slip from red to dark reddish grey. Burnished, medium lustre.

\section{Base-Ring Uncoated ware}

No. 23: Juglet, Inv. No. $8956 \mathrm{~V}_{1-2}\{2002 / 109\}$

(Fig. 3b: 2, Pl. 3:5)

Field reference: H/VI-x/19, Pl. 1-2, L4840(L), stratum d (= Phase C/3) ), a dump with a large amount of pottery sherds (L4840 and L4840 A to H).

\begin{tabular}{|c|c|c|c|c|c|c|}
\hline $\mathrm{P}$ & $\mathrm{VI}$ & f.-med. & $\mathrm{Ha}_{1}$ & - & re & 3 \\
\hline
\end{tabular}

Neck and shoulder sherd, and a body sherd. Nd: $5.0 \mathrm{~cm}$ : Wd: $0.25 \mathrm{~cm}$; 1) $\mathrm{H}_{1}: 2.5+\mathrm{x} \mathrm{cm}$; 2) $\mathrm{H}_{1}: 1.0+\mathrm{x}$.

Surface colour: 5YR 7/1 light grey interior; $6 / 2$ pinkish grey exterior.

Break: 7.5YR 5/1 grey.

Inclusions: quartz ( $>0.25 \mathrm{~mm},>0.50 \mathrm{~mm}$ : abundant), crushed limestone particles $(>0.25 \mathrm{~mm}$ : few) and dark sand (very fine).

Decoration: a horizontal incised line on the neck-base and an incised line on the shoulder, probable a spiral. Burnished, matte lustre.

\section{BASE-RING II}

\section{Black Matte Slipped Ware}

No. 24, Jug, Inv. No. 8205Q \{2002/101\} (Fig. 3b: 3) Field reference: $H / I I I-r / 19, P l . ~ O-1$, an ash layer below the accumulation of earth produced by the excavation of the canal. $H: 4.70 \mathrm{~m}$.

\begin{tabular}{|l|c|c|c|c|c|c|} 
SP & VI & f.-med. & $\mathrm{Ha}_{1}$ & - & ox & 3 \\
\hline
\end{tabular}

Handle and body fragment; one strap handle, rectangular section. Md: ca. $9.0 \mathrm{~cm}$; Wd: $0.35 \mathrm{~cm}$; Hd: 1.3 x $0.55 \mathrm{~cm}$. Surface colour: 5YR 6/1-5/1 grey interior; slip: 5YR 5/1 grey-4/1 dark grey.

Break: 5YR 4/1 dark grey interior (thick zone); a very thin oxidation zone $(6 / 6$ reddish yellow) on the exterior

Inclusions: quartz $(>0.25 \mathrm{~mm},>0.50 \mathrm{~mm}$ : abundant; $<2$ $\mathrm{mm}$ : few), crushed limestone $(>0.25 \mathrm{~mm}$ : few) and dark sand (very fine).

Handle pushed through into the wall.

Decoration: two painted bands (5YR $8 / 1$ white) on the shoulder?

Burnished, matte lustre. ${ }^{31}$

\footnotetext{
31 It was checked by Kathryn O. Eriksson.
} 


\section{Abbreviations}

3 hardness in the Moh's modified scale

$\mathrm{Bd}$ base diameter

Bd.Ha hand-made base

BP brown burnished surface

f.-med. fine to medium quality of the groundmass

fine fine quality of the groundmass

$\mathrm{H}_{1} \quad$ total height of the vessel

$\mathrm{H}_{3} \quad$ height of the neck

$\mathrm{Ha}_{1} \quad$ hand-made shaping technique

me fired in a medium atmosphere

No. $1 / 8956$ Q

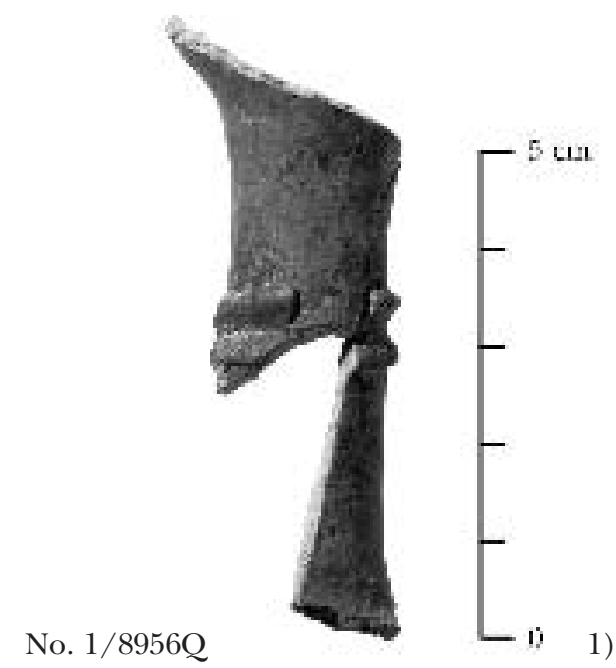

$\begin{array}{ll}\text { ox } & \text { fired in an oxidizing atmosphere } \\ \mathrm{P} & \text { polished } \\ \mathrm{Rd} & \text { rim diameter } \\ \text { re } & \text { fired in controlled firing conditions } \\ \mathrm{RP} & \text { red burnished surface } \\ \mathrm{RP} / \mathrm{SP} & \text { red to black burnished surface } \\ \mathrm{SP} & \text { black burnished surface } \\ \mathrm{VI} & \begin{array}{l}\text { fabric of Cypriote origin in the Tell el-Dabca fab- } \\ \text { ric system }\end{array} \\ \mathrm{Wd} & \text { wall thickness }\end{array}$

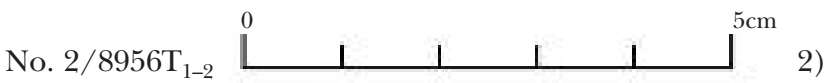
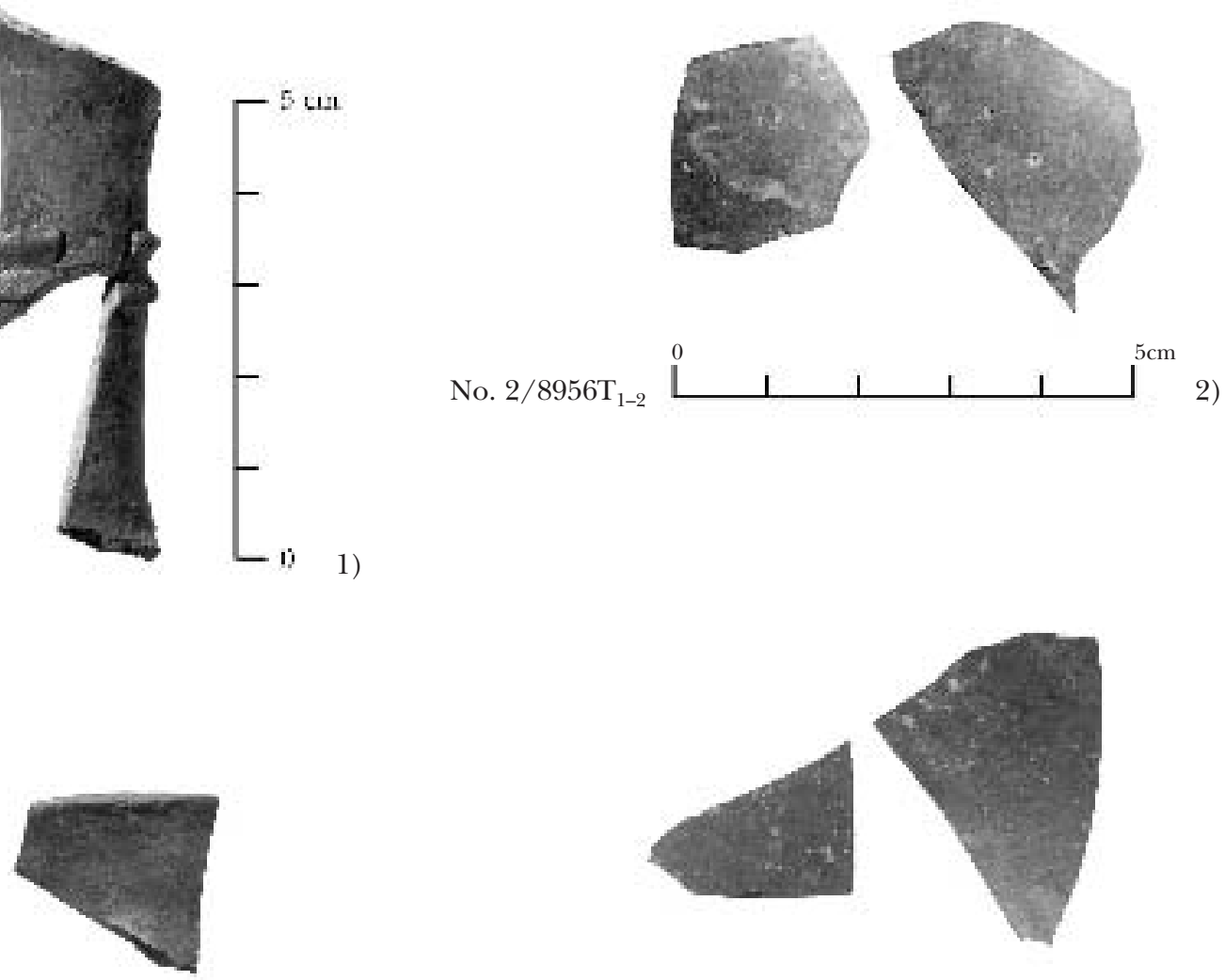

No. 4/8953U

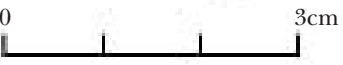

3)
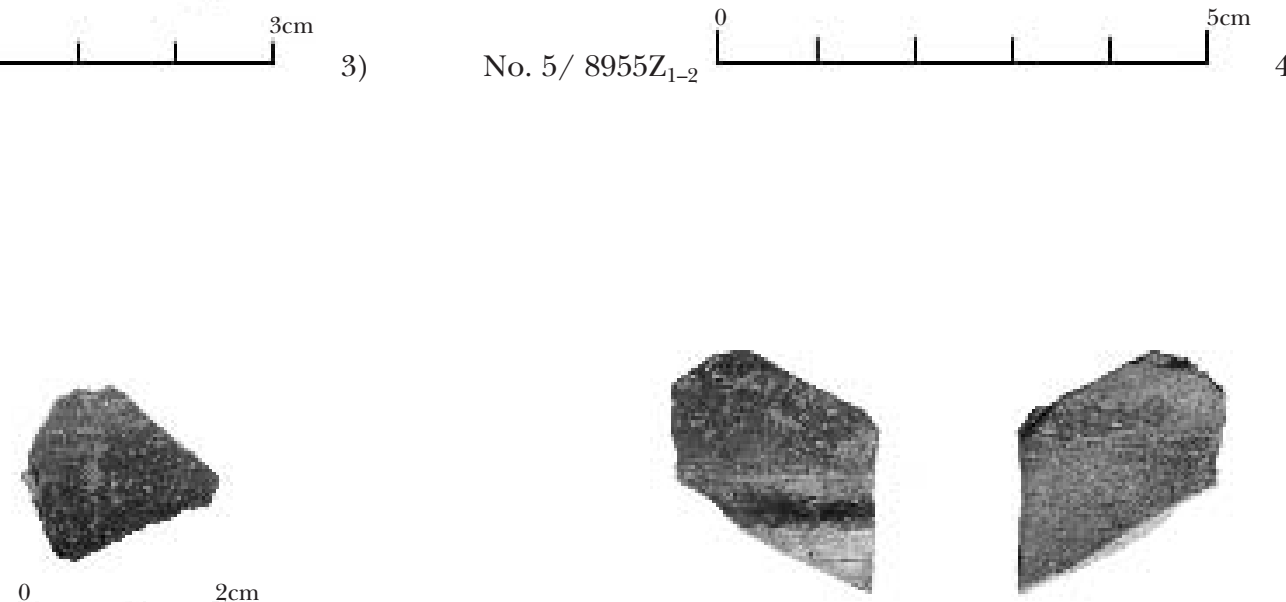

No. 6/8957A
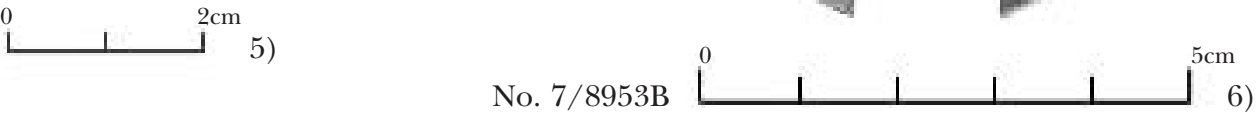

Plate 1 

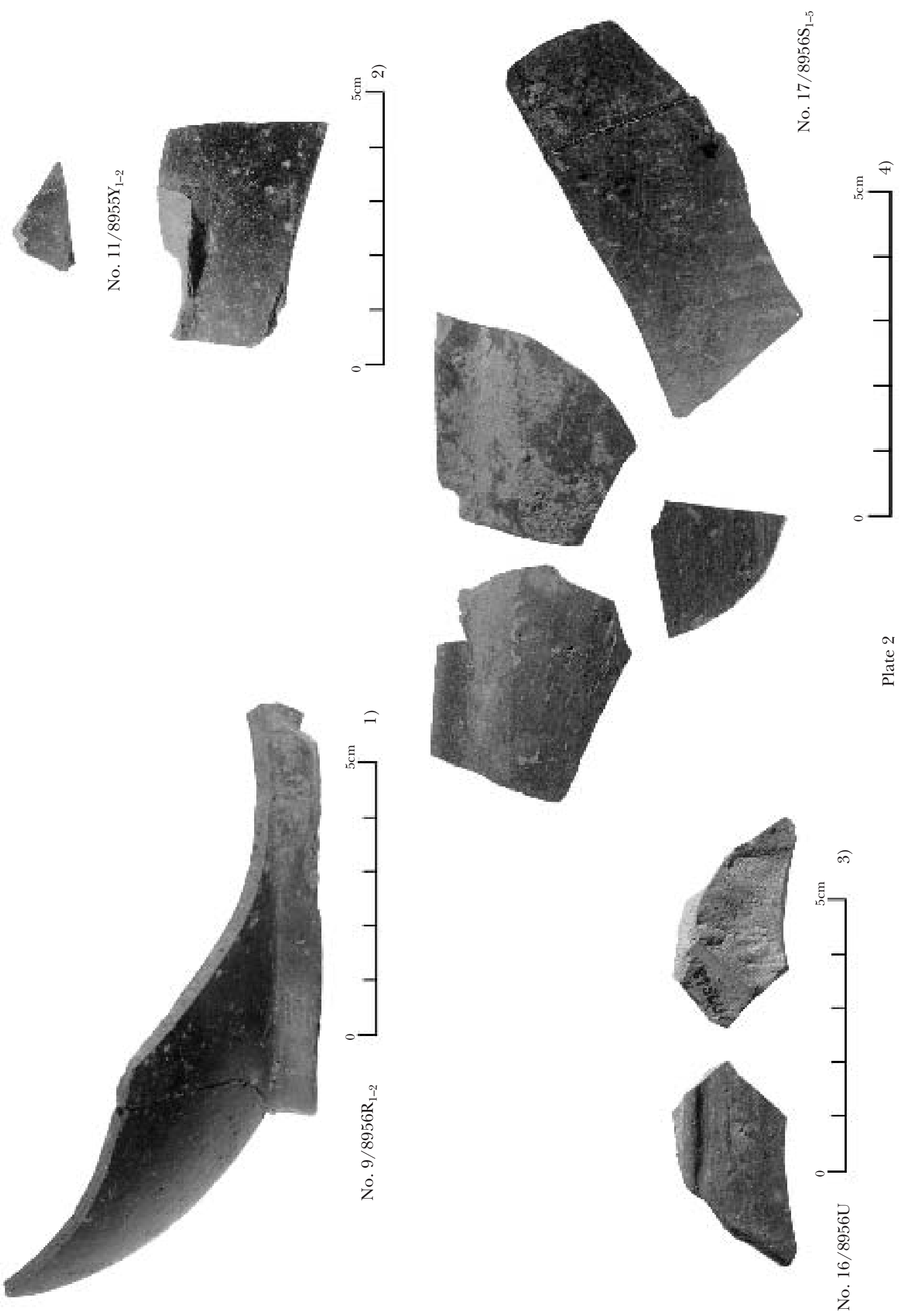

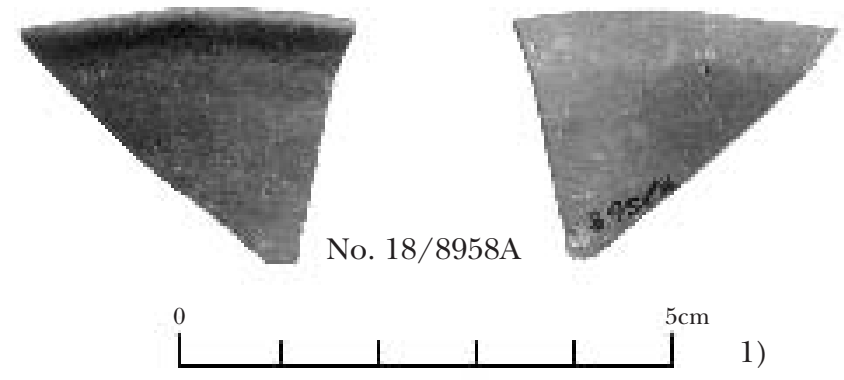
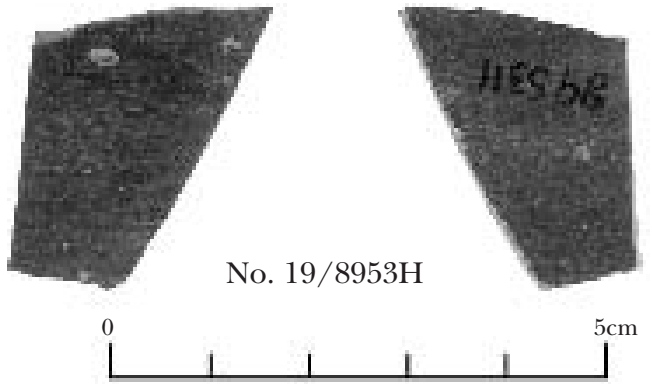

2)

No. $21 / 8956 W_{1-4}$
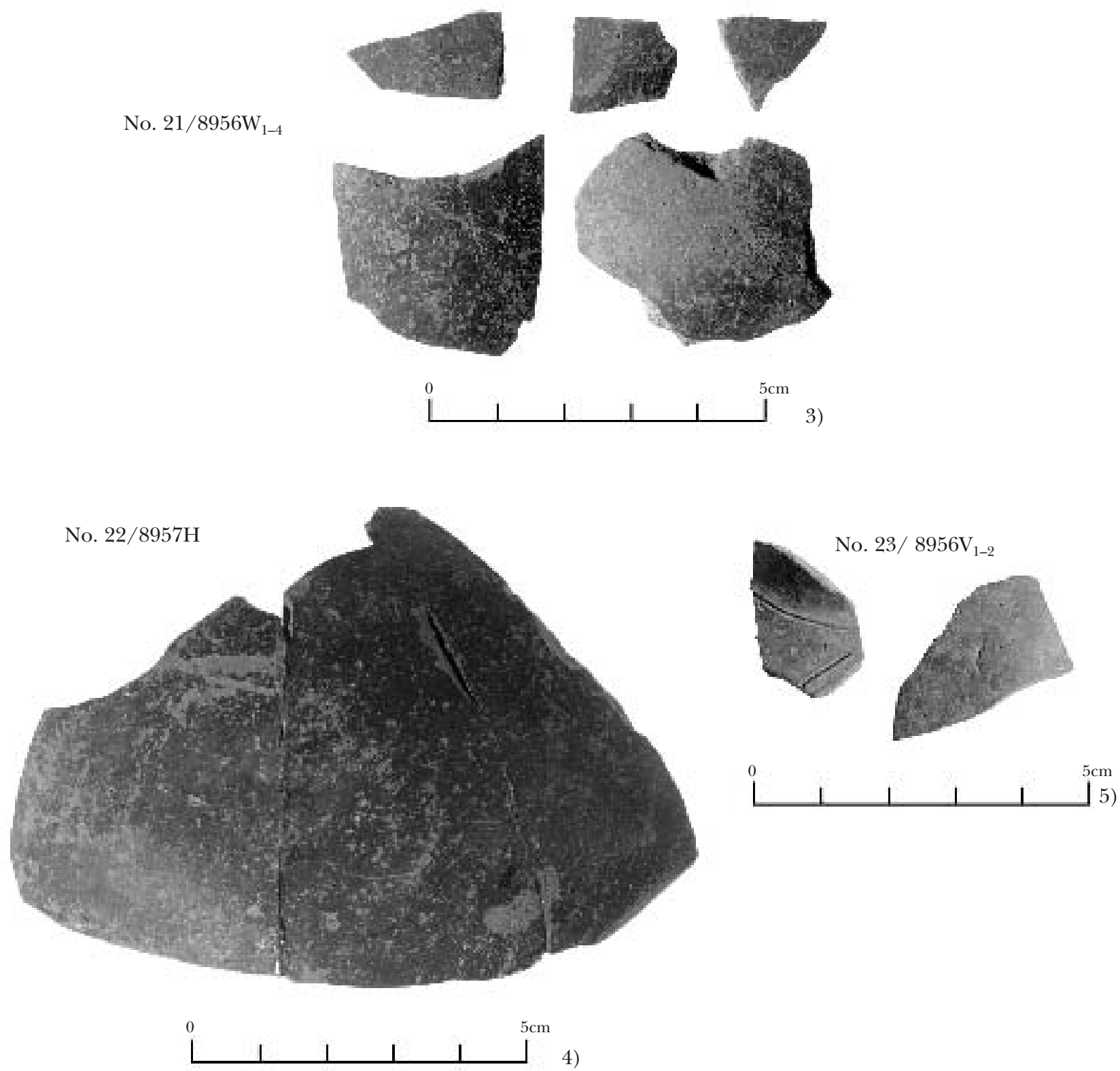

Plate 3 

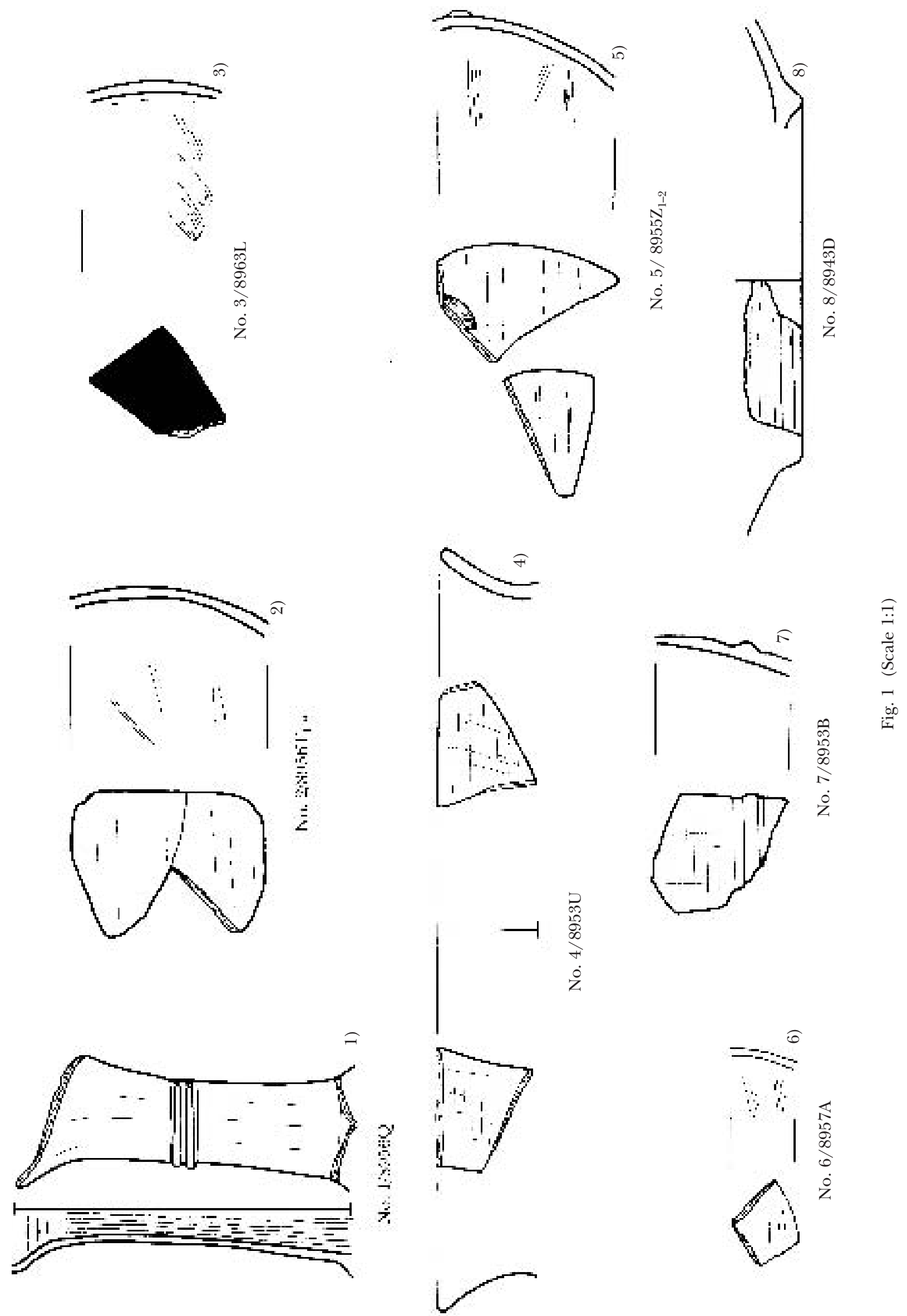

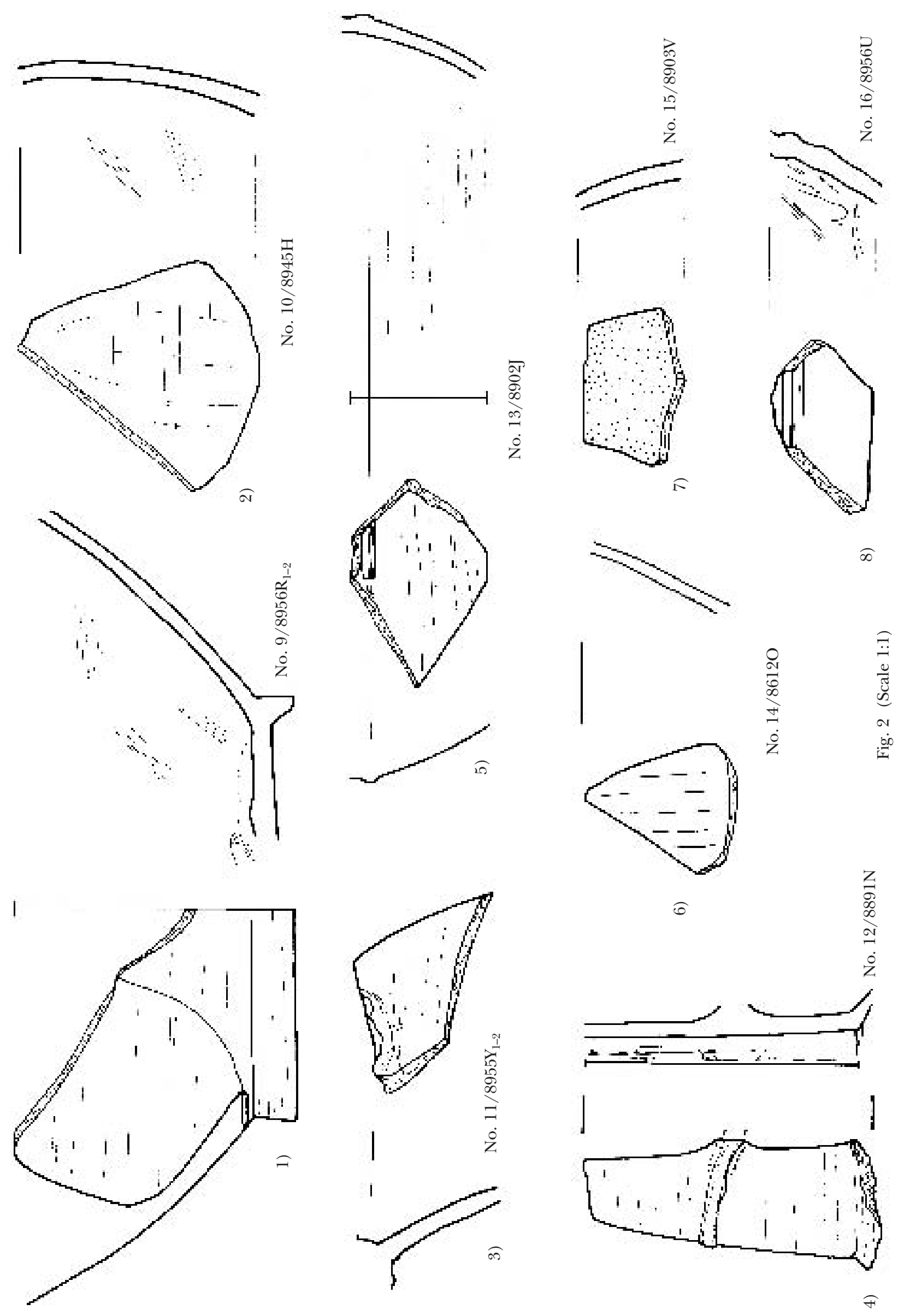

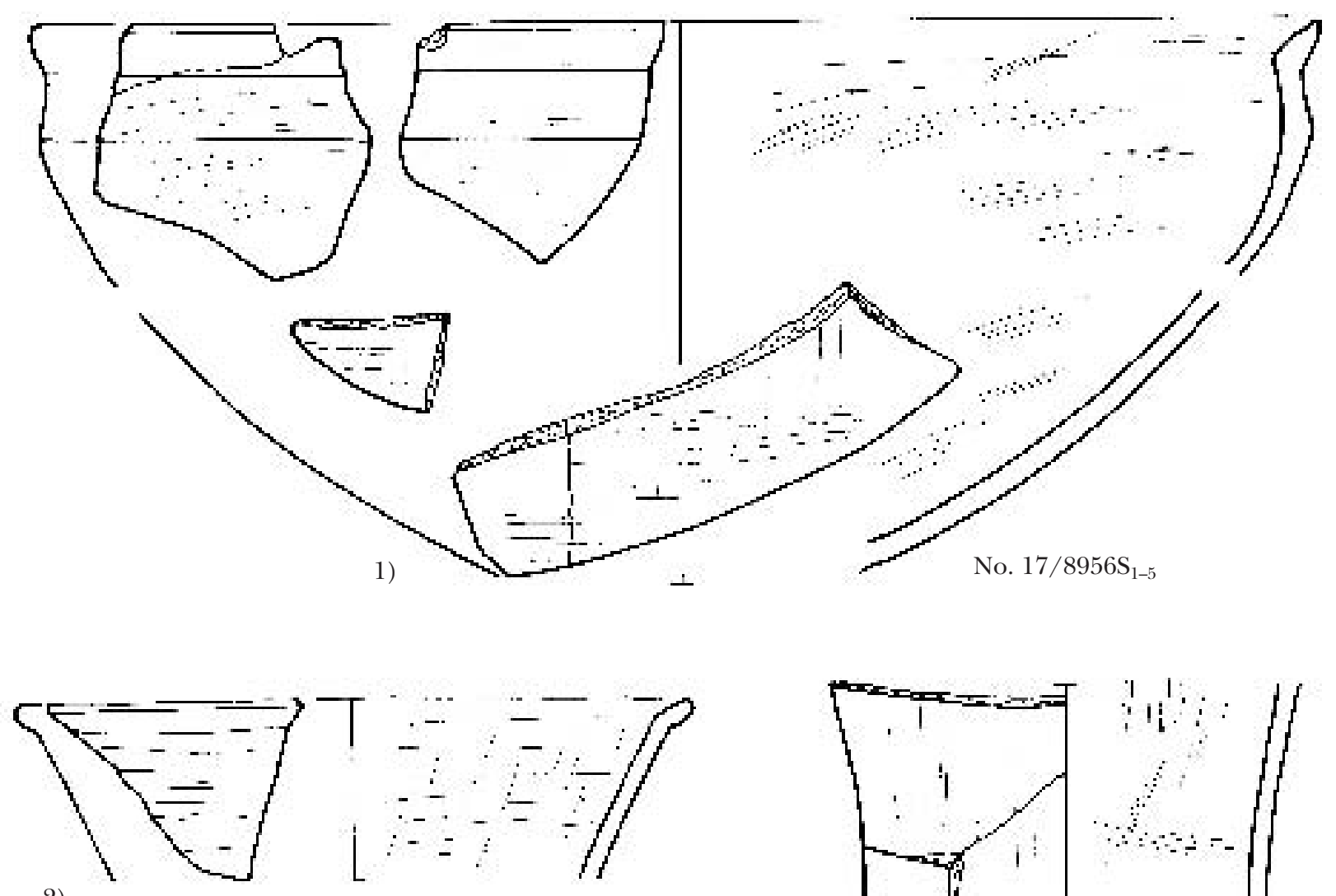

2)

No. $18 / 8958$ A
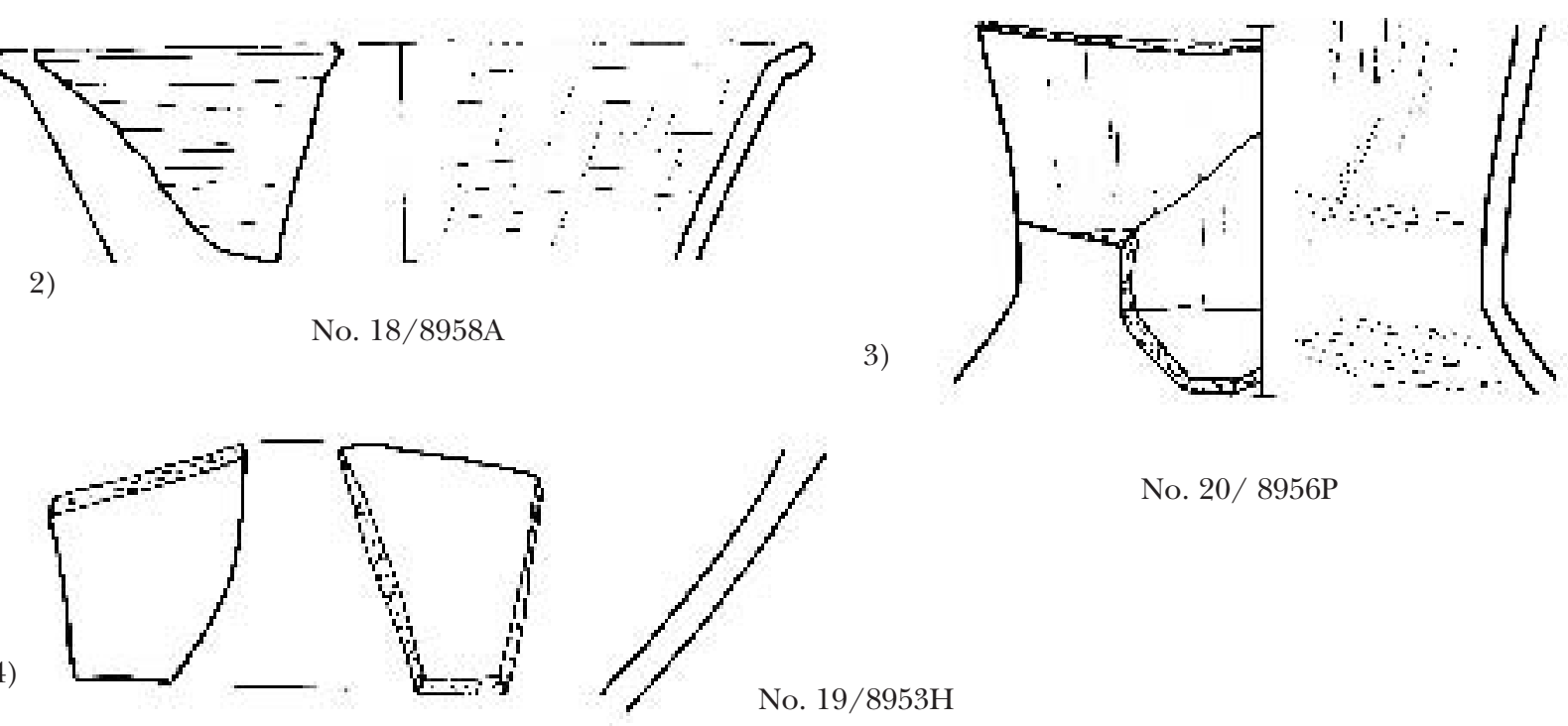

No. 20/ 8956P
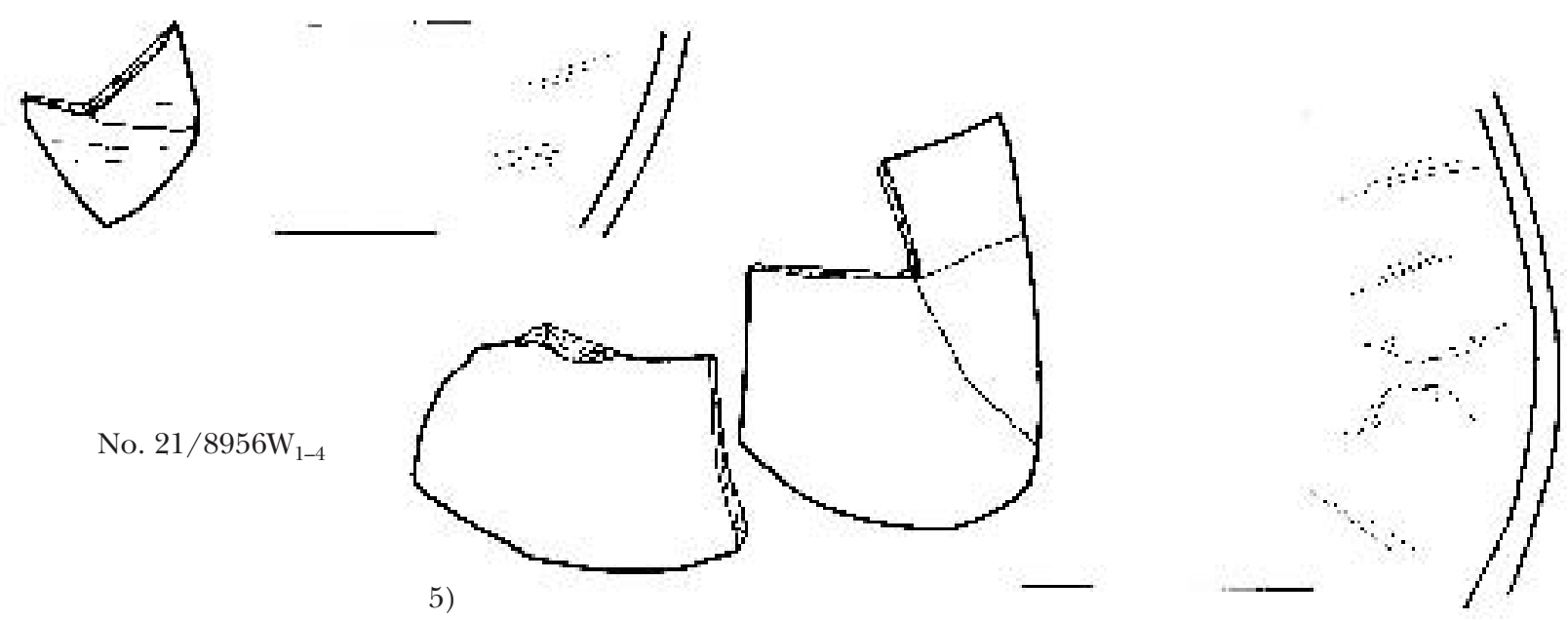

Fig. 3a (Scale 1:1) 
1)

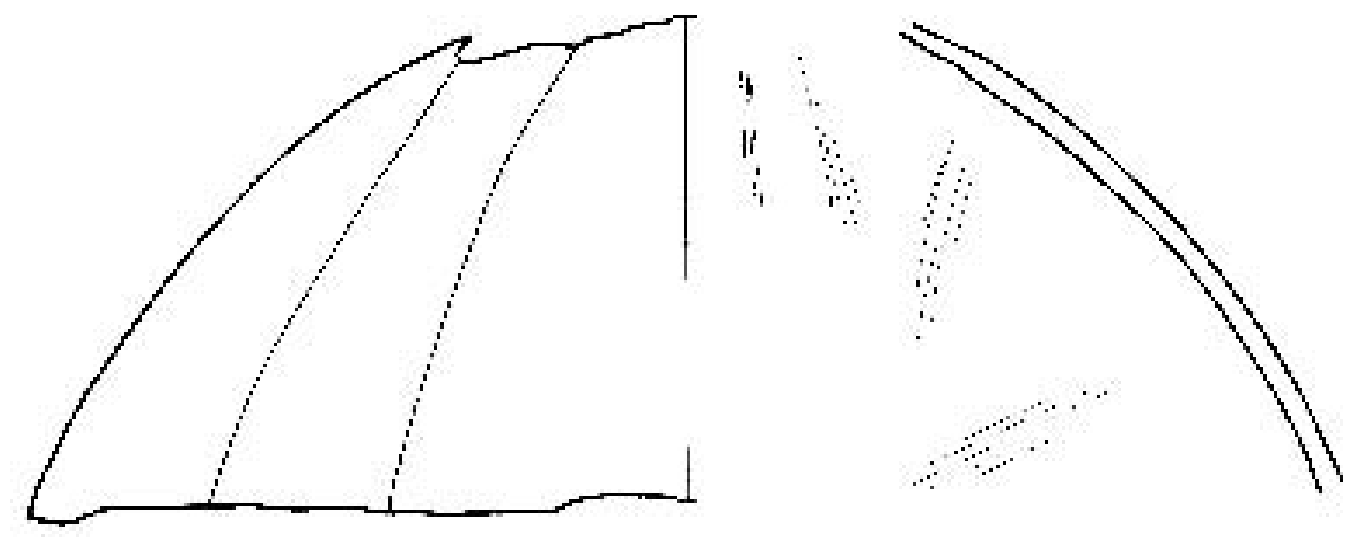

No. $22 / 8957 \mathrm{H}$

2)
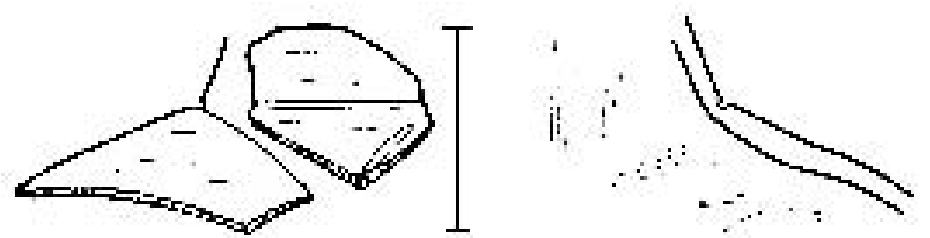

No. 23/ $8956 V_{1-2}$
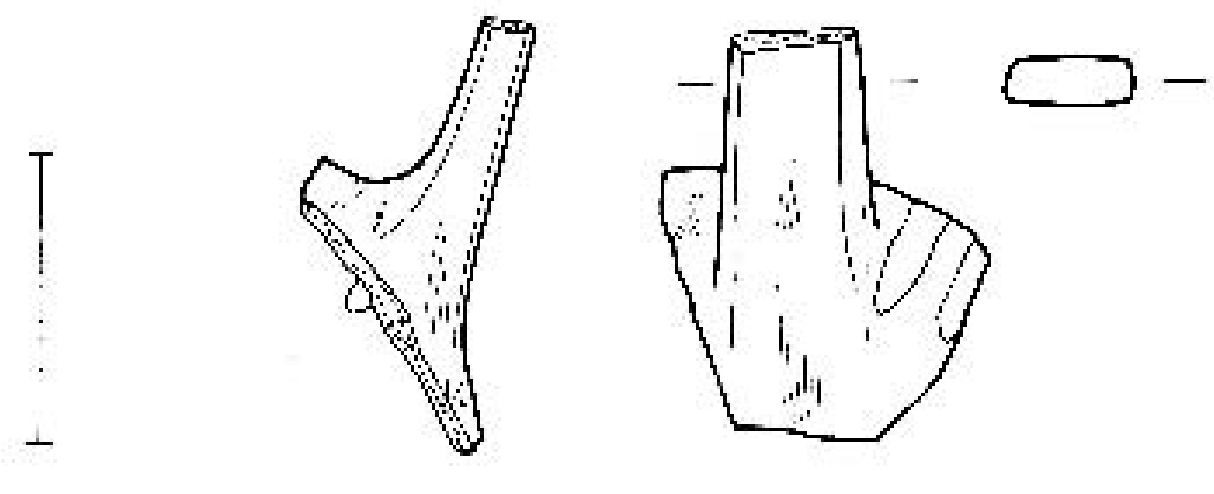

3) $\perp$

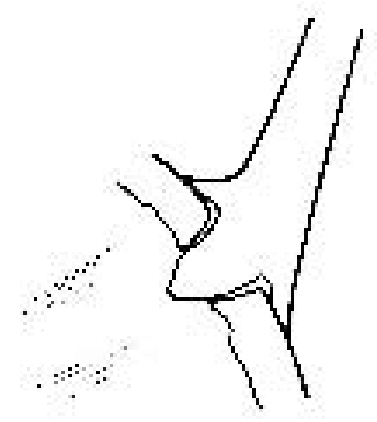

No. 24/ 8205Q

Fig. 3b (Scale 1:1) 